\title{
温水洗浄便座で生成した次亜塩素酸水の緑膿菌に対する除菌効果
} 伊丹 愛子 ${ }^{1,3)}$ ・莱原 $\quad$ 京子 $^{2)}$ ・堀 賢 ${ }^{1)}$

\section{Eradication Effect of Electrolyzed Hypochlorous Acid Water Produced by Electronic Bidet Toilet Seat System against Pseudomonas aeruginosa}

\author{
Aiko ItAmi ${ }^{1,3)}$, Kyoko KUWAHARA ${ }^{2)}$ and Satoshi HorI ${ }^{1)}$ \\ 1) Department of Infection Control Science, Graduate School of Medicine, Juntendo University, \\ ${ }^{2)}$ Department of Microbiology, School of Medicine, Juntendo University, ${ }^{3)}$ Department of Research Institute, TOTO LTD.
}

$(2017$ 年 8 月 10 日受付 $\cdot 2017$ 年 12 月 5 日受理)

\begin{abstract}
要旨
近年, 温水洗浄便座の污染が医療関連感染の原因菌を媒介しない衛生的な温水洗浄便座が求めら れている. 最新の温水洗浄便座では, 水道水を電気分解して次带塩素酸水（中性電解水）を生成し， ノズルを洗浄する機能を有している製品がある ${ }^{1,2)}$. 本研究では, 次車塩素酸水生成機能付き便座 で生成された低濃度中性電解水を用いて, 医療関連感染で問題となりやすい緑膿菌に対する, 除菌 効果を明らかにすることを目的として本研究を実施した，その結果，緑膿菌臨床分離株，環境分離 株とも次曲塩素酸濃度 $0.5 \mathrm{mg} / \mathrm{L}$ で 30 秒以上, $1.0 \mathrm{mg} / \mathrm{L}$ で 5 秒以上接触させることで, $90 \%$ 以上 の株で菌濃度 2 桁以上の除菌効果が得られた. 以上の結果から, 中性電解水は, 低濃度でも接触時 間と作用間隔を最適化すれば，緑膿菌に対して除菌効果があることが示唆された.
\end{abstract}

Key words：温水洗浄便座, 緑膿菌, 中性電解水, 除菌

序文

温水洗浄便座の世带普及率は $81.2 \%$ に達して抢り, 医 療現場でも広く普及している。近年, 環境を介した水平 伝播防止の観点から, 温水洗浄便座の污染が医療関連感 染の原因菌を媒介しない衛生的な温水洗浄便座が求めら れている，最新の温水洗浄便座の一つには，水道水を電 気分解して次亜塩素酸水 (中性電解水) を生成し, ノズ ルを洗浄する機能を有している. 来原らの研究3) は, 事 前にノズルを培養液に浸し $35^{\circ} \mathrm{C} て ゙ 2$ 日間培養後, ノズ ル表面にバイオフィルムが付着した状態からの中性電解 水の洗浄条件について報告して抢り, 実際の使用条件と は大きく異なっている．私たちは，ノズルに付着した污 染菌が増殖する前に中性電解水で定期的に洗浄すれば, 菌の過利な増殖を抑制できると考えた，本研究では，医 療施設で問題となりやすい緑膿菌を用いて, 培養時間と 菌の増殖の関倸及び, 液中での中性電解水の除菌効果を

1) 順天堂大学大学院感染制御科学, 2) 順天堂大学微生物学, 3) TOTO 株式会社総合研究所
明らかにすることを目的とした．

\section{材料と方法}

\section{1. 試験菌株}

順天堂医院で 2015 年 2016 年に入院患者から分離さ れた緑膿菌臨床分離株 44 株 (このうち, PCR-based ORF Typing (POT 法) のみ 28 株), 水まわり污れから分離 された緑膿菌環境分離株 8 株を用いた。

\section{2. 菌の前培養}

保存菌株から普通寒天平板培地に 1 白金耳移植し, 温 度 $35 \pm 1^{\circ} \mathrm{C}$ で 20 時間培養した。

\section{3. 試験菌液の調整}

試験菌の菌体 1 白金耳量を 500 倍に希釈したニュート リエントブロス（以後 $1 / 500 \mathrm{NB}$ ）にミキサーで均一に 分散させる. 分光光度計において $600 \mathrm{~nm}$ の波長で透過 率が $70 \%$ となるように菌液濃度を調製することで, 菌 液濃度を約 $10^{8} \mathrm{cfu} / \mathrm{mL}$ に調製した. 調製した菌液を，1/ $500 \mathrm{NB}$ を用いて，規定濃度に希釈し試験菌液とした。 


\section{4. 混釈培養法による菌数測定}

菌液をミキサーでよく攪拌後に 10 倍希釈系列を作製 し, 標準寒天培地で混釈後, $35 \pm 1^{\circ} \mathrm{C}$ で 48 時間培養し た. 培養後, 原則として $30 \sim 300 \mathrm{cfu} /$ シャーレの集落が 出現した希棌系列のコロニー数を計測した。

\section{5. 緑膿菌增殖試験方法}

JIS Z2801 抗菌加工製品一抗菌性試験方法) に準拠し て増殖を観察した。

\section{1）試験片の清浄化}

$5 \mathrm{~cm}$ 角の ABS プレートを, 99\%エタノールを吸収 させた脱脂綿で軽く $2 \sim 3$ 回拭いた後, 十分乾燥し試験 片とした。

\section{2）菌液の接種}

約 $10^{4} \mathrm{cfu} / \mathrm{mL}$ に調製した試験菌液をピペットで試験 片 1 枚当たり $300 \mu \mathrm{L}$ 接種した。 ピンセットを用いて 4 $\mathrm{cm}$ 角ストマッカーフィルムをのせ, 試験菌液がフィル ム全体に行きわたるようにピンセットで軽く押さえつけ た後, 培養した。

\section{3）培養}

試験菌液を接種した試験片の入ったシャーレを $35^{\circ} \mathrm{C}$ $\pm 1^{\circ} \mathrm{C}$ ，相対湿度 $90 \%$ 以上で $4 ， 8 ， 12$ 時間培養した。

\section{4）菌液の回収}

規定時間培養後, 試験片を滅菌済ストマッカー袋内に いれ，これにピペットで生理食塩水 $9 \mathrm{~mL}$ を加え手で十 分にもみ, 試験菌を洗い出した，洗い出し液の $1 \mathrm{~mL}$ 当 たりの菌数を混䣋培養法により測定した.

\section{6. 中性電解水殺菌試験方法}

1）中性電解水の調製

実機カットモデル内の白金族系触媒をコーティングし た次亜塩素酸生成電極を有する電解槽に, 遊離残留塩素 を除去した神奈川県茅ヶ崎市が供給する水道水（pH 7.5 \pm 0.1 に調製）を通水し, 中性電解水を生成した。実際 の温水洗浄便座では, 水質, 温度, 使用期間等によって 生成される次亜塩素酸濃度は変動するが, 本研究では 0.3 $\mathrm{mg} / \mathrm{L}, 0.5 \mathrm{mg} / \mathrm{L}$ 及び $1.0 \mathrm{mg} / \mathrm{L}$ の中性電解水を生成し た.

\section{2）菌液の接種}

約 $10^{7} \mathrm{cfu} / \mathrm{mL}$ に調整した試験菌液を, 磁性スターラー で攪拌している中性電解水 $49.5 \mathrm{~mL} に 0.5 \mathrm{~mL}$ 接種した.

3）菌液の回収

$5 ， 30 ， 60$ 秒反応させた後，10\% チオ硫酸ナトリウム $50 \mu \mathrm{L}$ が入った滅菌シャーレに $1 \mathrm{~mL}$ 分取した。 それと 同時にさらに $1 \mathrm{~mL}$ を分取し， $0.1 \%$ チオ硫酸ナトリウ ムを含有した生理食塩水 $9 \mathrm{~mL}$ に加えてよく摚拌した. この回収液の $1 \mathrm{~mL}$ 当たりの菌数を混釈培養法により測 定した.

\section{PCR-based ORF Typing (POT) 法によるタイピ ング}

1）遺伝子抽出と遺伝子増幅法

シカジーニアス ${ }^{\circledR} \mathrm{DNA}$ 抽出試薬（関東化学株式会社, 東京）を用いて緑膿菌臨床分離株及び環境分離株の遺伝 子抽出を行った。緑膿菌用シカジーニアス ${ }^{\circledR}$ 分子疫学解 析 POT キット（関東化学, 東京) を用いて PCR を行っ た。

\section{2）アガロースゲル電気泳動}

$1 \times \mathrm{TBE}$ 緩衝液を用いた $4 \%$ アガロースゲルを用いて, $120 \mathrm{~V}$ で約 1 時間電気泳動を行った。 その後, 臭化エチ ジウム溶液に 30 分浸漬後, UVトランスイルミネーター 下でゲルの写真撮影を行った.

\section{3） POT 型の決定}

電気泳動後のバンドパターンから, 緑膿菌用シカジー ニアス分子疫学解析 POT キット (関東化学) の取扱説 明書に従い POT 型を決定した。

\section{結 果}

\section{1. 緑膿菌増殖試験}

緑膿菌臨床分離株 44 株, 緑膿菌環境分離株 8 株を, 培 養時間が 4, 8， 12 時間の時点で 10 倍あるいは 100 倍以 上 $\left(\mathrm{cfu} / \mathrm{cm}^{2}\right)$ 増殖した菌株の割合を示す（図 1).

臨床分離株は，4 時間では 10 倍以上増殖した株は $0 \%$ （0/44 株）であった８時間では，増殖 10 倍未満の株が $89 \%$ (39/44 株)， 10 倍以上 100 倍未満増殖した株が $11 \%$ (5/44 株) であった. 12 時間では, 増殖 10 倍未満の株 が 43\% (19/44 株)，10 倍以上 100 倍未満増殖した株が $27 \%$ (12/44 株）となり， 100 倍以上増殖した株が $34 \%$ (15/44 株) であった。

一方環境分離株は, 4 時間では 10 倍以上増殖した株 は $0 \%(0 / 8$ 株）であった. 8 時間では， 10 倍以上 100 倍未満増殖した株が $13 \%$ (1/8 株) であった。 12 時間 では，10 倍以上 100 倍未満増殖した株が $38 \%$ (3/8 株) となり，100 倍以上増殖した株が $63 \%$ (5/8 株) となっ た.

\section{2. 中性電解水殺菌試験}

中性電解水での緑膿菌臨床分離株及び環境分離株の殺 菌試験の結果を示す (図 2). 生菌数が 2 桁 $(\mathrm{cfu} / \mathrm{ml})$ 以 上減少した場合に「除菌された」と定義し，各濃度での， 除菌に至らなかった株の割合を生存率として示した。

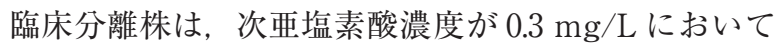
は，接触時間が 5 秒間では $2 \%$ (1/44 株)， 30 秒間では 95\%（42/44 株）の株が除菌された。また， $0.5 \mathrm{mg} / \mathrm{L} に$ おいては，5秒間で $68 \%$ (30/44 株)， 30 秒間では $100 \%$ (44/44 株) の株が除菌された. $1.0 \mathrm{mg} / \mathrm{L}$ においては, 5 秒間で $100 \%$ の株が除菌された。

一方環境分離株は, 次亜塩素酸濃度が $0.3 \mathrm{mg} / \mathrm{L} に お ~$ 


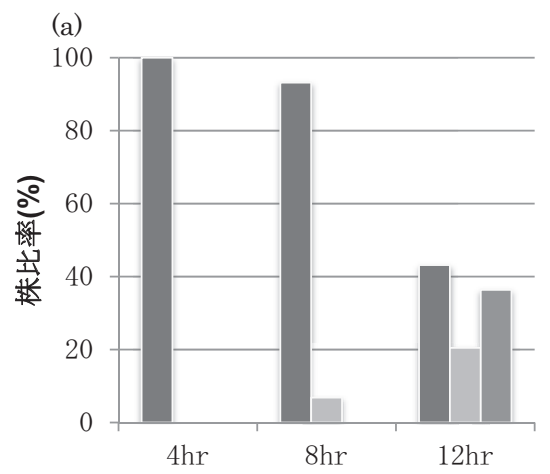

図 1 緑膿菌増殖試験結果

培養開始後の増殖の様子を経時的に示す。（a）緑膿菌臨床分離株，（b）緑膿菌環境分離株 であり，増殖の程度は， 10 倍未満， 10 倍以上 100 倍未満, 100 倍以上で表記して いる.
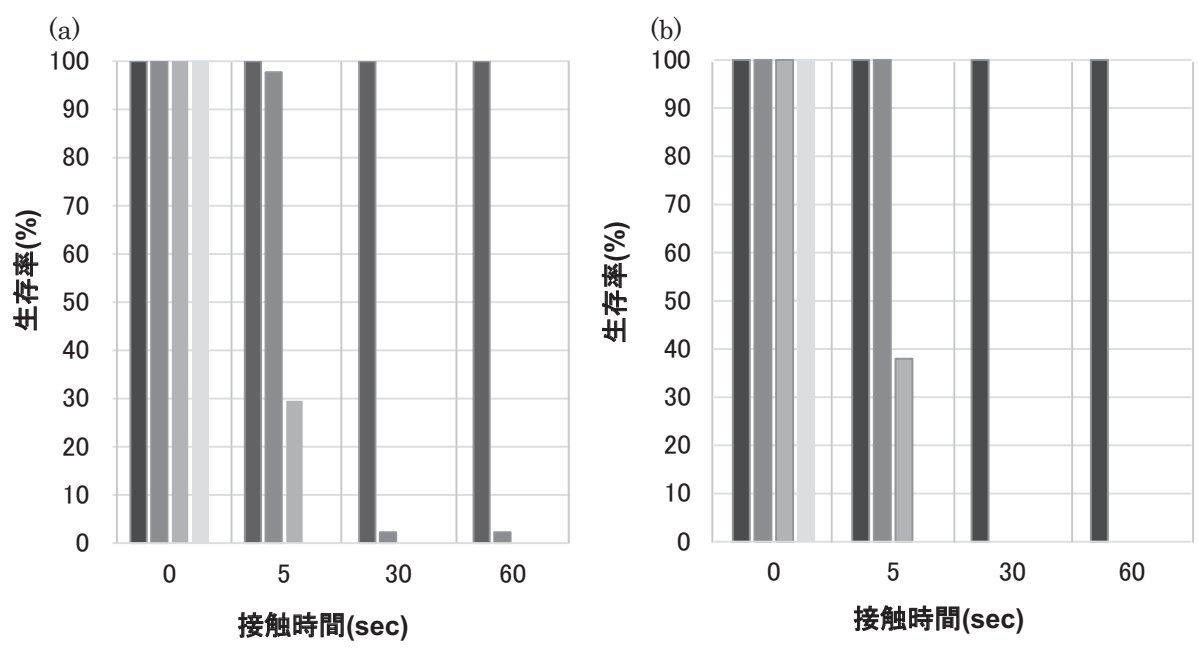

図 2 中性電解水による殺菌試験

中世電解水による除菌試験結果を示す。（a）緑膿菌臨床分離株，（b）緑膿菌環境分離株であり，次 亜塩素酸濃度はそれぞれ， $0.0 \mathrm{mg} / \mathrm{L} ， 0.3 \mathrm{mg} / \mathrm{L} ， 0.5 \mathrm{mg} / \mathrm{L}, \quad 1.0 \mathrm{mg} / \mathrm{L}$ で表記してある。

いては，接触時間 30 秒間で $100 \%$ （8/8 株）の株が除菌

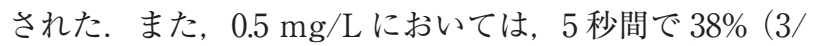
8 株)，30 秒間では $100 \%$ ( $8 / 8$ 株)の株が除菌された。 1.0 $\mathrm{mg} / \mathrm{L}$ においては，5秒間で 100\%（8/8 株）の株が除菌 された。

図 3 に次带塩素酸濃度と接触時間を掛け合わせた值 (以下 $\mathrm{CT}$ 值) と除菌可能な緑膿菌株の割合を示した。 そ の結果から, CT 值がある一定以上を超えると急激に除 菌可能な株の割合が上昇し, 約 $0.07(\mathrm{mg} \cdot \mathrm{min} / \mathrm{L})$ 以 上の時, 除菌可能な株の割合が $90 \%$ を超えることが示 された。

\section{POT 法による遺伝子タイピング}

表 1 に臨床分離株及び環境分離株の同一 POT 型の検 出株数と, 同一POT 型の検出頻度を示した. POT1, POT2 ともに同一の值の場合同一の株とみなした。臨床

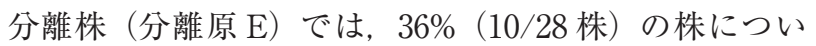

て同一の株が得られたのに対し，環境分離株 (分離原 C) では，13\%（1/8 株）について同一の株が得られた.

\section{考察}

緑膿菌増殖試験において，緑膿菌臨床分離株と環境分 離株を比較すると，培養時間 4 時間， 8 時間では培養挙 動に違いが見られなかったが, 12 時間培養時点で増殖 一桁未満の株が, 臨床分離株では 43\% (19/44 株)であっ たのに対し，環境分離株では $0 \%(0 / 8$ 株）であり，環 境分離株は臨床分離株と比べょり多くの株で増殖するこ とが示された。本研究の試験条件が，栄養レベルを低く 抑えた状態での，増殖挙動である，そのことから，人か ら分離された臨床分離株と比較して，水まわり環境から 分離された環境分離の方が低栄養条件において, 増殖速 度が早いことが示唆された。

中性電解水殺菌試験では, 次亜塩素酸の濃度が上がる 


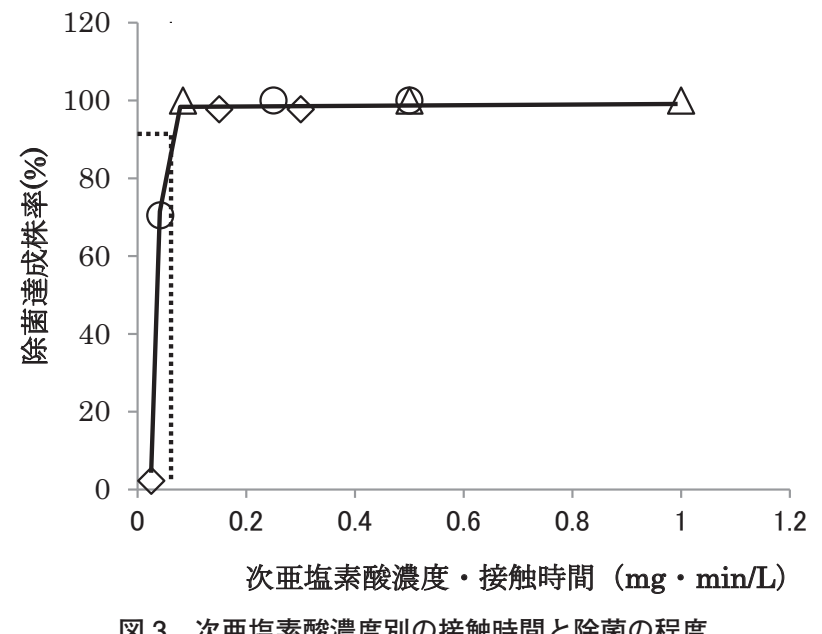

図 3 次亜塩素酸濃度別の接触時間と除菌の程度

次亜塩素酸との接触時間と 2 枌以上の除菌を達成できた菌株の割 合を次亜塩素酸濃度別に示す. 次亜塩素酸は, $\diamond 0.3 \mathrm{mg} / \mathrm{L}, \bigcirc$ $0.5 \mathrm{mg} / \mathrm{L}, \triangle 1.0 \mathrm{mg} / \mathrm{L}$ で表記してある.

に従って除菌可能な株の割合が増えることが示されたが, 緑膿菌環境分離株と臨床分離株では明確な違いは見られ なかった．本研究のような水道水を電気分解して得られ る低濃度の中性電解水においても, CT 值を規定值以上 とすることによって, 緑膿菌に対して除菌効果があると 推察された。

一方で, POT 法を用いた遺伝子夕イピングによる遺 伝的多様性の検討では, 緑膿菌臨床分離株は環境分離株 と比べて同一株が検出される割合が高くなった，本研究 で使用した環境分離株は 8 株と少ないため, 明確な有意 差は見られないものの，環境分離株の方が臨床分離株と 比較して, 遺伝的多様性が大きいことが示唆された. 過 去の知見からも同じ病院内で分離された細菌と比較して, 市中で分離された細菌は遺伝的多様性が大きいとの報告 がある ${ }^{5}$. つまり当院においては, 感染経路は特定でき ないが, 通院患者間で緑膿菌が水平伝播した可能性も否 定できない. そのことから, 中性電解水のノズル洗浄機 能を導入することで水平伝播のリスクを低減する効果が あると考えられる。

\section{結論}

臨床分離株, 環境分離株ともに培養時間 8 時間では, 2 桁以上増殖した株が $0 \%(0 / 44$ 株， $0 / 8$ 株）であったの に対し，培養時間 12 時間では，2桁以上増殖した株が $40 \%$ 以上（18/44 株，5/8株）となった. 以上から中性 電解水での温水洗浄便座ノズルの洗浄間隔は, 菌が 2 桁 以上増殖する前の 8 時間以下とすることが望ましいと考 えられた。

$\mathrm{CT}$ 值を 0.07 以上とすることで, 除菌効果が得られた ことから，適正な濃度と洗浄時間を設定することで，ノ ズルを除菌可能であることが示唆された.
表 1 臨床分離株の同一POT 型の検出株数を POT 型別に表示する.

\begin{tabular}{|c|c|c|c|}
\hline 分離原 & POT1 & РОТ2 & 検出株数（株） \\
\hline C & 387 & 32 & 3 \\
\hline C & 472 & 0 & 2 \\
\hline C & 201 & 16 & 2 \\
\hline C & 46 & 0 & 2 \\
\hline$C, E$ & 105 & 16 & 2 \\
\hline C & 574 & 16 & 1 \\
\hline C & 574 & 0 & 1 \\
\hline C & 123 & 0 & 1 \\
\hline C & 118 & 0 & 1 \\
\hline C & 44 & 0 & 1 \\
\hline C & 575 & 0 & 1 \\
\hline C & 383 & 0 & 1 \\
\hline C & 314 & 48 & 1 \\
\hline C & 93 & 0 & 1 \\
\hline C & 125 & 16 & 1 \\
\hline C & 54 & 0 & 1 \\
\hline C & 121 & 0 & 1 \\
\hline C & 415 & 0 & 1 \\
\hline C & 636 & 48 & 1 \\
\hline C & 392 & 0 & 1 \\
\hline C & 894 & 0 & 1 \\
\hline C & 319 & 4 & 1 \\
\hline C & 294 & 0 & 1 \\
\hline E & 538 & 48 & 1 \\
\hline E & 223 & 18 & 1 \\
\hline E & 894 & 48 & 1 \\
\hline E & 206 & 20 & 1 \\
\hline E & 895 & 48 & 1 \\
\hline E & 887 & 18 & 1 \\
\hline$E$ & 392 & 50 & 1 \\
\hline Total & & & 36 \\
\hline
\end{tabular}

検出頻度は, 総検体数に占める各 POT 型の割合 である。

臨床分離株を分離原 C，環境分離株を分離原 $\mathrm{E}$ とした.

\section{利益相反自己申告 :}

伊丹愛子は TOTO 株式会社の社員である.

堀賢は TOTO 株式会社から研究資金援助を受けている.

\section{文献}

1）石井克典, 佐藤基和, 梅本 涉, 林 香里：トイレ機器の 衛生管理に用いる水道電解水の水質安全性. 機能水研究 2016; 12: 1-2.

2）日本機能水学会編, 次亜塩素酸水生成装置に関する指針, 第 2 版-追補，機能水研究振興財団，2013.

3）莱原京子, 左 卉, 堀 賢: 温水洗浄便座の洗浄ノズ ルの除菌条件の検討. 日本環境感染学会 2017; 32: 127-30.

4) 日本工業標準調查会：抗菌加工製品一抗菌性試験方法・抗 菌効果 (Z2801)。 日本工業規格.

5）児玉佑希子, 渡辺瑞希, 竹下朱美, 小島栄一, 庄野伸浩, 森 山康司: 水道水の電解水による環境微生物の殺菌効果. 防 菌防徽 2011; 39: 279-83. 
6) Grundmann H, Hori S, Tanner G: Determining Confidence Intervals When Measuring Genetic Diversity and the Discriminatory Abilities of Typing Methods for Microorganisms. Journal of clinical microbiology 2001; 39: 4190-2.
〔連絡先：邓253-8577 神奈川県茅ヶ崎市本村 2-8-1 TOTO 株式会社総合研究所分析技術第一 G 伊丹愛子 E-mail: aiko.itami@jp.toto.com]

\title{
Eradication Effect of Electrolyzed Hypochlorous Acid Water Produced by Electronic Bidet Toilet Seat System against Pseudomonas aeruginosa
}

\author{
Aiko Itami ${ }^{1,3)}$, Kyoko KUWAHARA ${ }^{2)}$ and Satoshi HorI ${ }^{1)}$ \\ ${ }^{1)}$ Department of Infection Control Science, Graduate School of Medicine, Juntendo University, \\ ${ }^{2)}$ Department of Microbiology, School of Medicine, Juntendo University, ${ }^{3)}$ Department of Research Institute, TOTO LTD.
}

\section{Abstract}

In recent years, specifications with more stringent hygienic requirements have been needed for toilet seats with electronic bidet sprayers to prevent their contamination and transmission of pathogens responsible for healthcare-associated infections. Some of the latest models of bidet toilet seats are designed to electrolyze tap water and produce hypochlorous acid water (neutral electrolyzed water) to cleanse the spray nozzles ${ }^{1,2)}$. This study was performed to clarify the optimal conditions of nozzle cleansing eradication of bacteria effect with low-concentration neutral electrolyzed water using clinical and environmental isolates of Pseudomonas aeruginosa as a common pathogen causing healthcare-associated infection. Exposure to neutral electrolyzed water having a chlorine concentration of $0.5 \mathrm{mg} / \mathrm{L}$ for $30 \mathrm{~s}$ or longer, or of $1.0 \mathrm{mg} / \mathrm{L}$ for $5 \mathrm{~s}$ or longer, led to a 2-log or more decrease in the level of $P$. aeruginosa for $90 \%$ or more of the strains of both clinical and environmental isolates, thereby demonstrating the eradication of bacteria effect. The results suggest that, for eradication of bacteria against $P$. aeruginosa, neutral electrolyzed water is effective even at low concentrations, provided that the exposure time and intervals are optimized.

Key words: electronic bidet toilet seat, Pseudomonas aeruginosa, neutral electrolyzed water, eradication of bacteria 